\title{
PENERAPAN MODEL PEMBELAJARAN TEACHING FACTORY 6 LANGKAH (MODEL TF-6M) UNTUK MENINGKATKAN MOTIVASI BERPRESTASI SISWA DI SMK
}

\author{
Akhmad F. Amar', Dadang Hidayat ${ }^{2}$, Amay Suherman ${ }^{3}$ \\ Departemen Pendidikan Teknik Mesin \\ Universitas Pendidikan Indonesia \\ Jl. Dr. Setiabudhi No. 207 Bandung 40154 \\ akhmadfaisalamar@gmail.com
}

\begin{abstract}
ABSTRAK
Tujuan penelitian ini adalah untuk mengetahui apakah terjadi peningkatan motivasi berprestasi siswa dan untuk mengetahui bagaimanakah peningkatan motivasi berprestasi siswa setelah mendapatkan pembelajaran Teaching Factory 6 Langkah (Model TF-6M). Objek dari penelitian ini adalah siswa kelas XI B SMK Negeri 1 Majalengka Kompetensi Keahlian Teknik Sepeda Motor yang berjumlah 34 siswa. Penelitian ini dilakukan dengan menggunakan metode quasi experiment dengan desain one-group pretest-posttest design. Instrumen yang digunakan pada penelitian ini berupa angket. Motivasi berprestasi siswa mengalami peningkatan setelah mendapatkan pembelajaran Model TF-6M. Peningkatan ketercapaian skor dan $n$-gain masing-masing sebesar $59,91 \%$ dan 0,07 .
\end{abstract}

Kata kunci: teaching factory, model TF-6M, motivasi, mekanik

\section{PENDAHULUAN}

Pendidikan merupakan suatu usaha yang dilakukan secara terencana, sistematis, dan logis dalam membina insan manusia menuju proses pendewasaan sesuai dengan kebutuhan dan tuntutan hidup lingkungan. Pendidikan dapat dilakukan melalui pendidikan jalur informal, nonformal, dan formal. Sekolah sebagai lembaga pendidikan formal selain bertujuan mendewasakan anak, juga diperlukan untuk memajukan dan mencerdaskan kehidupan bangsa. Sebagaimana dikemukakan di dalam pasal 3 UU No.20 Tahun 2003 tentang sistem Pendidikan Nasional, yaitu: Pendidikan nasioanal berfungsi mengembangkan kemampuan dan membentuk watak serta peradaban bangsa yang bermartabat dalam rangka mencerdaskan kehidupan bangsa. Bertujuan untuk berkembangnya potensi siswa agar menjadi manusia yang beriman dan bertaqwa kepada Tuhan Yang Maha Esa, berakhlak mulia, sehat, berilmu, cakap, kreatif dan bertanggung jawab.

\footnotetext{
${ }^{1}$ Mahasiswa Departemen Pendidikan Teknik Mesin FPTK UPI

${ }^{2}$ Dosen Departemen Pendidikan Teknik Mesin FPTK UPI

${ }^{3}$ Dosen Departemen Pendidikan Teknik Mesin FPTK UPI
} 
Salah satu keberhasilan siswa dalam pendidikan ditunjukkan dengan prestasi akademiknya. Pada kenyataannya ditemukan tuntutan prestasi akademik pada siswa semakin tinggi sementara daya belajarnya biasa-biasa saja. Hal inilah yang menyebabkan tingkat keberhasilan siswa dalam prestasi akademik kurang sebagaimana diharapkan oleh sekolah, orang tua dan siswa itu sendiri (Sagala, 2013).

Fungsi pendidikan salah satunya adalah membentuk sikap dan orientasi siswa terhadap belajar, menanamkan sikap positif dan haus akan pengetahuan serta untuk mengembangkan keterampilan belajar secara efektif (Syamsudin, 2009). Keberhasilan siswa dalam pendidikannya juga dipengaruhi oleh motivasi berprestasi yang dimiliki. Motivasi berprestasi sebagai daya dorong yang memungkinkan seseorang berhasil mencapai apa yang diidamkan (Sugiyanto, 2007). Seseorang yang memiliki motivasi berprestasi tinggi cenderung untuk selalu berusaha mencapai apa yang diinginkan walaupun mengalami hambatan dan kesulitan dalam meraihnya. Pada kenyataannya motivasi berprestasi yang dimiliki oleh seseorang cenderung sering mengalami penurunan dan di waktu lain mengalami peningkatan. Motivasi berprestasi yang dimiliki seseorang idealnya selalu mengalami progresif atau kemajuan sehingga akan mempercepat apa yang diidamkan (Handoko, 1992). Hal inilah yang belum dimiliki oleh generasi muda untuk selalu meningkat motivasi berprestasinya.

Hasil belajar dipengaruhi oleh berbagai faktor, baik faktor dari dalam (internal) maupun faktor dari luar (eksternal). Faktor internal adalah faktor fisiologis dan psikologis (misalnya kecerdasan motivasi berprestasi dan kemampuan kognitif), sedangkan yang termasuk faktor eksternal adalah faktor lingkungan dan instrumental (misalnya guru, kurikulum, dan model pembelajaran) (Slameto, 2003).

Berdasarkan pendapat tersebut perlu diungkap salah satu faktor internal yaitu kurangnya motivasi berprestasi. Hal ini berkaitan dengan penulis selama mengikuti Program Pelatihan Lapangan dan melakukan observasi ke SMK Negeri 1 Majalengka terdapat 23 siswa dari 33 siswa atau 70\% dalam 1 kelas yang memperoleh nilai di bawah Kriteria Kelulusan Minimal (KKM) yang menerapkan model pembelajaran yang biasa diterapkan di sekolah. Peserta didik yang nilainya masih di bawah KKM dikarenakan peserta didik masih terlambat dalam menyelesaikan tugas, masih terdapat peserta didik yang membolos pada saat program belajar mengajar berlangsung dan peserta didik tidak bersemangat dalam mengikuti proses 
pembelajaran. Faktor tersebut merupakan kurangnya motivasi berprestasi yang terdapat dalam diri siswa tersebut (Purwanto, 2007).

Banyak ditemukan di lapangan bahwa guru menguasai materi suatu subjek dengan baik tetapi tidak dapat melaksanakan kegiatan pembelajaran dengan baik. Hal itu terjadi karena kegiatan tersebut tidak didasarkan pada model pembelajaran tertentu sehingga hasil belajar yang diperoleh siswa rendah. Timbul pertanyaan apakah mungkin dikembangkan suatu model pembelajaran yang sederhana, sistematik, bermakna dan dapat digunakan oleh para guru sebagai dasar untuk melaksanakan kegiatan pembelajaran dengan baik sehingga dapat membantu meningkatkan motivasi berprestasi dan hasil belajar (Uno, 2007).

Berkenaan dengan hal itu, maka dengan memperhatikan berbagai konsep dan teori belajar dikembangkanlah suatu model pembelajaran yang disebut dengan model pembelajaran Teaching Factory 6 langkah (Model TF-6M). Penerapan model pembelajaran TF-6M ini, suasana proses pembelajarannya dirancang seperti suasana industri yang nyata. Melalui model seperti ini diharapkan siswa dapat lebih banyak memahami tentang industri, dan siswa dengan lebih mudah mendalami ilmu pelajaran karena siswa dapat mengenal secara langsung pelajaran yang disampaikan oleh guru (Hidayat, 2010). Persentase waktu untuk siswa dapat melakukan praktik langsung akan jauh lebih banyak. Belajar dari pengalaman nyata diharapkan akan lebih jauh bermakna dan optimal dalam mengembangkan potensi siswa, daripada lebih banyak memaparkan teori di kelas dan sedikit melakukan praktik sesuai dengan program keahlian yang diambil di sekolah menengah kejuruan. Suasana industri yang diciptakan dalam model TF-6M diharapkan dapat lebih memberikan motivasi berprestasi kepada siswa.

\section{METODE PENELITIAN}

Lokasi penelitian dalam penelitian ini adalah SMKN 1 Majalengka yang beralamat di Jl. Tonjong-Pinangraja No.55 Cigasong Majalengka. Sample pada penelitian kali ini adalah XI TSM A dengan jumlah 33 siswa sebagai kelas control dan XI TSM B dengan jumlah 34 siswa sebagai kelas eksperimen. Penelitian ini menggunakan metode eksperimen semu (quasi experiment). Metode penelitian yang digunakan untuk mencari pengaruh perlakuan terhadap yang lain dalam kondisi yang terkendalikan. Desain penelitian dalam penelitian ini adalah non equivalent control group design. Dengan desain ini, baik kelompok eksperimental maupun 
kelompok kontrol dibandingkan, kendati kelompok tersebut dipilih dan ditempatkan tanpa melalui randomisasi (Emzir, 2010).

\section{HASIL PENELITIAN}

Hasil yang diperoleh dari penyebaran angket untuk motivasi berprestasi siswa terdapat 38 item pernyataan sebagai berikut:

Tabel 1. Motivasi Berprestasi Kelas Eksperimen dan Kelas Kontrol

\begin{tabular}{ccc}
\hline \multicolumn{2}{c}{ Kelas } & Rata-rata Persentase Ketercapaian Skor \\
\hline \multirow{2}{*}{ Eksperimen } & Pretest & $49,46 \%$ \\
& Postest & $59,91 \%$ \\
\multirow{2}{*}{ Kontrol } & Pretest & $51,73 \%$ \\
& Postest & $54,55 \%$ \\
\hline
\end{tabular}

Hasil rata-rata persentase ketercapaian skor yang didapat oleh kelas eksperimen dan kelas kontrol (Tabel 1). Saat pretest dilakukan menunjukkan bahwa motivasi berprestasi siswa kelas eksperimen memperoleh rata-rata ketercapaian skor sebesar 49,46\% dan kelas kontrol sebesar 51,73\%, dari maksimum persentase ketercapaian skor yang diharapkan adalah 100\%. Rata-rata persentase ketercapaian skor pada saat postest motivasi berprestasi siswa kelas. Berdasarkan analisa data penelitian yang terlihat peningkatan $N$-Gain yang didapat oleh masing-masing siswa. Gain tersebut kemudian dinormalisasi untuk mengetahui kriteria peningkatan motivasi berprestasi siswa yang didapat masing-masing siswa. Berikut terlihat perbandingan rata-rata $\mathrm{N}$-Gain kedua kelas yang digambarkan pada gambar di bawah ini.

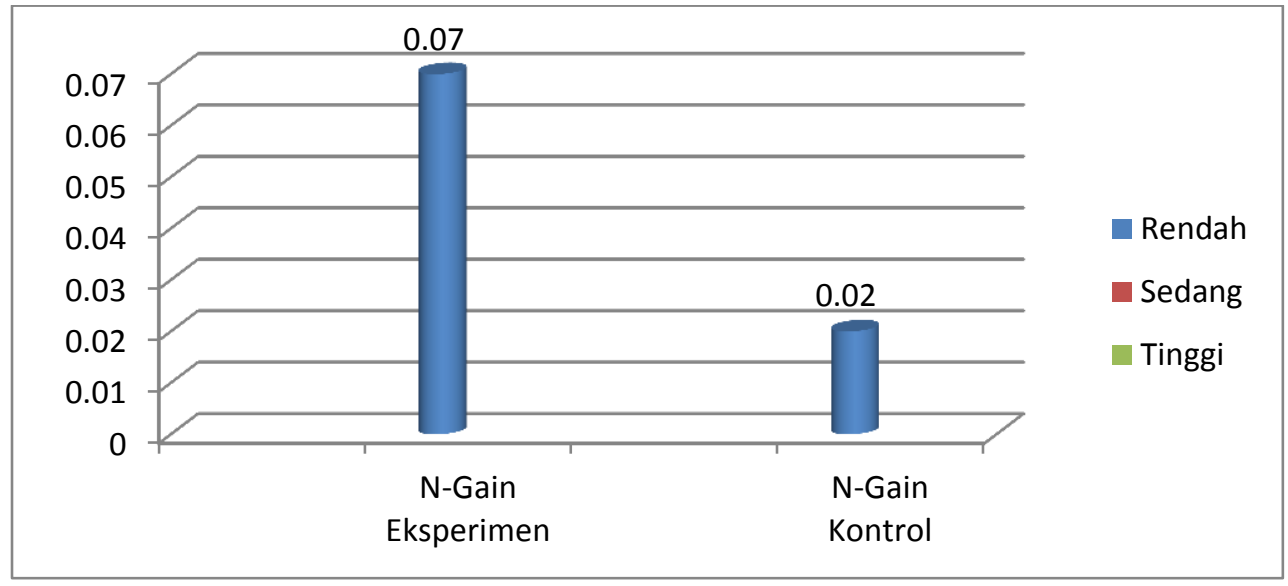

Gambar 1. N-Gain Motivasi Berprestasi Siswa Kelas Eksperimen dan Kelas Kontrol 
Hasil rata-rata $N$-Gain (Gambar 1) dari kelas eksperimen lebih besar daripada rata-rata $N$-Gain kelas kontrol. Hasil rata-rata $N$-Gain kedua kelas berada pada kategori rendah. Melihat hasil perbandingan $\mathrm{N}$-Gain antara kelas eksperimen dan kelas kontrol. Berikut ini adalah sebaran nilai $\mathrm{N}$-Gain yang diperoleh masing-masing siswa pada kelas eksperimen dan kontrol.

\section{PEMBAHASAN}

Penelitian ini dilakukan pada siswa SMK Negeri 1 Majalengka tahun ajaran 2012/2013, dimana jumlah responden dalam penelitian ini adalah sebanyak 67 siswa kompetensi keahlian teknik sepeda motor. Jumlah tersebut terbagi dalam dua kelompok, 34 siswa berada pada kelas eksperimen dan 33 siswa berada pada kelas kontrol. Variabel penelitian yang telah ditentukan yaitu penerapan model pembelajaran TF-6M dan motivasi berprestasi siswa kompetensi keahlian teknik sepeda motor. Pembahasan penelitian ini memberikan gambaran hasil penelitian secara terperinci, berdasarkan pada teori-teori maupun konsep-konsep yang relevan, dimana penelitian ini menggunakan metode eksperimen semu atau disebut kuasi eksperimen.

Pelaksanaan penelitian ini menggunakan instrumen angket untuk mengetahui motivasi berprestasi siswa, dimana instrumen ini terdiri dari 38 item soal yang terdiri dari beberapa aspek motivasi berprestasi siswa. Penelitian yang dilakukan di kelas XI teknik sepeda motor SMK Negeri 1 Majalengka ini, bermaksud untuk membuktikan teori bahwa model pembelajaran yang digunakan sesuai tujuan pembelajaran dapat mempengaruhi motivasi berprestasi siswa. Pelaksanaan model pembelajaran Teaching Factory 6 Langkah (Model TF6M) yang dilakukan mengacu pada pelaksanaan industri jasa otomotif perbaikan sepeda motor, dimana siswa merasakan bagaimana industri jasa otomotif yang dikombinasikan dengan proses belajar mengajar. Pelaksanaan penelitian ini bermaksud untuk merangsang munculnya dorongan faktor internal dari dalam diri siswa yang berupa mempunyai tanggung jawab pribadi, menetapkan nilai standar unggulan, belajar dengan kreatif, mencapai cita-cita, melakukan kegiatan sebaik-baiknya dan melakukan antisipasi. Sehingga pengaruh tersebut dapat meningkatkan motivasi berprestasi siswa kelas XI kompetensi keahlian sepeda motor.

Berdasarkan hasil dari postest kedua kelas, melalui perhitungan persentase ketercapaian skor setelah postest dilakukan, rata-rata persentase ketercapaian skor dari kelas eksperimen adalah sebesar 59,91 \%, dan untuk kelas kontrol adalah 54,55 \%, hal ini 
menunjukkan bahwa adanya peningkatan motivasi berprestasi siswa kelas eksperimen setelah diberikan perlakuan model pembelajaran TF-6M. Kelas eksperimen mendapatkan jauh lebih banyak pengalaman untuk aktif dalam proses belajar mengajar. Melihat dari hasil persentase ketercapaian skor postest, terlihat peningkatan motivasi berprestasi siswa kelas eksperimen pada masing-masing indikator motivasi berprestasi siswa. Berdasarkan landasan teori mengenai model pembelajaran TF-6M. Ketika pelaksanaan model pembelajaran ini, proses belajar mengajar yang berbeda membuat siswa merasakan pengalaman yang berbeda pula. Siswa mendapatkan pelajaran yang sangat berharga yang tidak pernah mereka dapatkan dengan model pembelajaran yang biasa dilakukan di sekolah. Pembelajaran yang biasa dilakukan di sekolah membuat siswa kurang aktif dan produktif untuk selalu belajar kompetensi yang harus siswa miliki.

Hasil yang diperoleh dari penelitian menunjukkan bahwa siswa mempunyai tanggung jawab pribadi dalam motivasi berprestasi siswa di kalangan siswa kelas eksperimen naik sebesar $14,52 \%$, dengan nilai $\mathrm{N}$-Gain 0,31 yang berada pada kategori sedang. Peningkatan siswa mempunyai tanggung jawab pribadi ini dikarenakan pada model pembelajaran TF-6M siswa memperoleh banyak pengalaman yang baik untuk memupuk sikap pekerja keras, tidak mudah menyerah, memiliki semangat, dan memiliki bertanggung jawab. Hal ini ditunjukkan dengan proses pembelajaran pada beberapa langkah kerja di model pembelajaran TF-6M. Langkah kerja mengerjakan order, siswa mengerjakan order dengan bekerja keras agar order yang dikerjakan selesai dengan benar dan tepat waktu, dan tentunya pada saat mengerjakan order siswa juga terpacu untuk tidak mudah menyerah dan memiliki semangat yang baik. Sikap bertanggung jawab juga ditunjukkan pada saat langkah menyatakan kesiapan mengerjakan order, siswa mempunyai tanggung jawab kepada konsumen untuk dapat mengerjakan order dengan baik dan tepat waktu.

Berdasarkan hasil yang diperoleh dari penelitian ini, menunjukkan bahwa siswa yang menetapkan nilai yang akan dicapai kelas eksperimen mengalami peningkatan sebesar 5,15\%, dengan nilai $\mathrm{N}$-Gain sebesar 0,14 yang masuk dalam kategori rendah. Walaupun peningkatan dalam kategori rendah, nilai peningkatan untuk kelas eksperimen jauh lebih besar daripada kelas kontrol yang memakai model pembelajaran biasa. Langkah kerja TF-6M memacu siswa untuk berusaha berfikir positif terhadap setiap order yang dikerjakan, siswa yakin dapat mengerjakan order dengan baik sebelum mengerjakannya. Proses mengerjakan order juga 
memupuk siswa untuk mengerjakan order dengan sangat teliti dan sesuai dengan SOP yang sudah diterapkan, sehingga setiap pemeriksaan komponen kendaraan tidak ada yang terlewatkan satupun. Ketika siklus yang pertama, kemampuan siswa dalam mengerjakan order masih banyak kesalahan yang terjadi, tetapi karena siswa mau instropeksi diri dan ingin maju, pada siklus berikutnya siswa terlihat jauh lebih bagus mengerjakan order daripada siklus sebelumnya. Hal ini berhubungan karena pada model pembelajaran TF-6M memiliki standar nilai minimal yang harus dicapai oleh siswa.

Siswa yang selalu belajar dengan kreatif sangat berpengaruh terhadap pencapaian motivasi berprestasi siswa. Semakin kuat pembelajaran kreatif yang diterapkan siswa, kemungkinannya dia akan mempunyai motivasi berprestasi yang tinggi. Sebaliknya, semakin lemah pembelajaran kreatif yang diterapkan siswa, maka dia akan semakin sulit untuk mempunyai motivasi berprestasi siswa.

Penelitian ini juga menunjukkan bahwa pembelajaran kreatif yang diterapkan terhadap siswa, siswa kelas eksperimen mengalami peningkatan sebesar 3,15\%, dengan nilai $\mathrm{N}$-Gain sebesar 0,07 yang masuk dalam kategori rendah. Ditunjukkan dari beberapa pengalaman siswa yang diperoleh melalui model pembelajaran TF-6M ini. Tanpa adanya inisiatif belajar dengan kreatif untuk bertindak, kepercayaan diri, siswa tidak akan berani untuk menerima konsumen, menyatakan kesiapan mengerjakan order, menganalisa order, mengerjakan order, melakukan quality control, serta menyerahkan order ke konsumen. Peningkatan ini dikarenakan pada model pembelajaran TF-6M siswa tidak merasa jenuh karena model pembelajaran TF-6M menuntut siswa untuk lebih kreatif.

Model pembelajaran TF-6M juga mengajarkan siswa untuk mempunyai cita-cita yang akan dicapai. Hal ini ditunjukkan setiap kali siswa mengerjakan setiap indikator TF-6M dengan bersungguh-sungguh dengan dilandasi dengan keinginan siswa tersebut dalam mencapai cita-citanya.

Setelah dilakukan perlakuan model pembelajaran TF-6M, hasil yang diperoleh penelitian menunjukkan bahwa indikator mencapai cita-cita pada kelas eksperimen mengalami penurunan sebesar $-0,088 \%$, dengan nilai $\mathrm{N}$-Gain sebesar -0,02. Penurunan ini ditunjukkan adanya beberapa faktor yang mempengaruhi siswa untuk mencapai cita-cita. Penurunan ini dikarenakan masih ada beberapa siswa meragukan kemampuan diri sendiri untuk meraih citacita yang diinginkan. 
Indikator melakukan kegiatan sebaik-baiknya terjadi peningkatan sebesar 2,30\%, dengan nilai $\mathrm{N}$-Gain sebesar 0,07 yang masuk dalam kategori rendah. Proses TF-6M memupuk siswa untuk melakukan setiap langkah dengan sebaik-baiknya sesuai dengan tujuan model pembelajaran TF-6M. siswa diharuskan mampu menyenangkan konsumen melalui order yang dikerjakan dan komunikasi yang baik dengan konsumen tersebut.

Penerapan model pembelajaran TF-6M terhadap sikap melakukan antisipasi dalam meningkatkan motivasi berprestasi siswa masih belum mengalami peningkatan. Penurunan ini sebesar -2,20 \% dengan nilai $N$-gain $-0,07$, hal ini dikarenakan siswa tidak dapat mengantisipasi kegagalan atau kesulitan yang terjadi dalam pembelajaran TF-6M. Masih kurangnya kesadaran siswa untuk berkomunikasi dengan guru merupakan faktor siswa mengalami kesulitan dalam pembelajaran TF-6M.

Data yang dipaparkan membuktikan bahwa setiap indikator motivasi berprestasi siswa kelas eksperimen peningkatan dan penurunan jauh lebih baik daripada yang terjadi di kelas control yang setiap indikatornya mengalami penurunan. Seseorang yang memiliki motivasi berprestasi tinggi memiliki ciri-ciri sebagai berikut: (1) memiliki tanggung jawab yang tinggi pada tugasnya; (2) menetapkan tujuan yang menantang, sulit dan realistik; (3) memiliki harapan sukses; (4) melakukan usaha yang keras untuk mencapai kesuksesan; (5) tidak memikirkan kegagalan; dan (6) berusaha memperoleh hasil yang terbaik". Melalui model TF$6 \mathrm{M}$ terbukti bahwa model pembelajaran ini mampu memberikan pengalaman pribadi yang positif dan dapat meningkatkan motivasi berprestasi yang baik bagi siswa.

Model pembelajaran merupakan salah satu faktor yang dapat mempengaruhi meningkatnya motivasi berprestasi siswa. Meningkatnya motivasi berprestasi siswa adalah salah satu tujuan yang perlu dicapai melalui proses pembelajaran SMK, supaya tujuan SMK untuk menyiapkan siswa yang siap kerja dan mampu menghasilkan lulusan-lulusan terbaik dapat terwujud. Melalui hasil penelitian ini membuktikan bahwa model TF-6M dapat meningkatkan motivasi berprestasi siswa kompetensi teknik sepeda motor SMK Negeri 1 Majalengka, walaupun jika dilihat dari hasil rata-rata $\mathrm{N}$-Gain yang didapat, peningkatannya masih dalam kategori rendah. Pelaksanaan penelitian ini sudah sesuai dengan prosedur penelitian dan kajian teori yang ada. Akan tetapi, peningkatan yang masih dalam kategori rendah ini dikarenakan dalam meningkatkan motivasi berprestasi seseorang sangatlah tidak mudah. Motivasi berprestasi terbentuk dengan adanya pengalaman hidup secara 
berkelangsungan. Penelitian ini juga hanya memberikan pengalaman mengenai industri sebanyak lima kali proses pembelajaran. Sarana yang dimiliki oleh sekolah juga kurang memadai, dengan hanya mempunyai bike lift sebanyak 3 buah, membuat proses pembelajaran TF-6M kurang maksimal.

Adanya perbedaan peningkatan motivasi berprestasi antar kedua kelas dibuktikan dengan pengujian hipotesis yang membuktikan bahwa terjadi perbedaan peningkatan motivasi berprestasi siswa yang menggunakan model pembelajaran TF-6M dan siswa yang menggunakan model pembelajaran yang biasa dilakukan di sekolah. Sesuai dengan Martawijaya (2010, hlm. 423), model pembelajaran TF-6M dikembangkan mengacu pada beberapa konsep model dan teori pembelajaran, yaitu konstruktivisme, work based learning, production based learning, life skill dan Teaching Factory. Melalui gabungan teori-teori pembelajaran tersebut pembelajaran TF-6M siswa dapat meningkatkan motivasi berprestasi siswa, karena pada proses pembelajaran TF-6M dalam bidang jasa, pengalaman yang didapatkan siswa sama seperti halnya industri jasa otomotif. Hasil dari penelitian ini juga senada dengan siswa yang memiliki motivasi berprestasi yang kuat cenderung percaya diri, bertanggung jawab dengan tindakannya, memperhitungkan resiko, membuat perencanaan dengan bijaksana, menghemat waktu. Dengan demikian motivasi berprestasi merupakan suatu pertanda kesuksesan akademik dan kesuksesasan hidup.

\section{KESIMPULAN}

Motivasi berprestasi siswa mengalami peningkatan setelah mendapatkan pembelajaran Model TF-6M. Peningkatan ketercapaian skor 59,91\% dan $n$-gain sebesar 0,07.

\section{DAFTAR PUSTAKA}

Handoko, M. (1992). Motivasi Daya Penggerak Tingkah Laku. Yogyakarta: Karvision.

Hidayat, D. (2010). Pengembangan Model Pembelajaran Teaching Factory (Model TF-6M) untuk Meningkatkan Kompetensi Siswa dalam Mata Pelajaran Produktif Sekolah Menengah Kejuruan. Disertasi Program Studi Pengembangan Kurikulum SPs UPI. Bandung: Tidak diterbitkan.

Purwanto, N. (2007). Psikologi Pendidikan. Bandung: Remaja Rosdakarya.

Sagala, S. (2013). Konsep dan Makna Pembelajaran. Bandung: Alfabeta. 
Slameto, (2003). Belajar dan Faktor-Faktor yang Mempengaruhinya. Jakarta: Rineka Cipta.

Sugiyanto. (2007). Pentingnya Motivasi Berprestasi dalam Mencapai Keberhasilan Akademik Siswa. Jurnal Ilmiah Psikologi Pendidikan dan Bimbingan FIP UNY. 1-14.

Syamsudin, A. (2009). Psikologi Kependidikan Perangkat di dalam Pengajaran. Bandung: Remaja Rosdakarya.

Uno, H. B. (2007). Model Pembelajaran. Jakarta: Bumi Aksara. 